\title{
A latency measure of metacontrast
}

\author{
HALSEY H. MATTESON \\ Tulane University, New Orleans, Louisiana 70118 \\ and \\ THOMAS B. FLAHERTY \\ Central Connecticut State College, New Britain, Connecticut 06050
}

\begin{abstract}
Perceived-order latencies were obtained with stimulus-onset asynchronies (SOAs) ranging from -200 (test preceding surround) to $+200 \mathrm{msec}$. When the test stimulus preceded the surround, no appreciable change of latency was obtained; therefore, the results of the present study are in agreement with previous studies which found no effect of SOA on reaction time. Since effective brightness of a test stimulus is reduced maximally when the test stimulus precedes the masking stimulus by about 75 msec, the present study and previous reaction time studies indicate that mechanisms mediating latency are different from mechanisms mediating brightness.
\end{abstract}

Since reduction of test stimulus luminance increases perceptual latency (Alpern, 1954; Arden \& Weale, 1954; Vaughan, Costa, \& Gilden, 1966), it might be expected that reduction of test stimulus brightness by means other than reduction of luminance would increase perceptual latency. Under conditions of metacontrast, maximum reduction of effective test stimulus brightness occurs when the test stimulus precedes the masking stimulus (surround) by 50 to $125 \mathrm{msec}$ (Alpern, 1953; Matteson, 1969; Schiller \& Smith, 1966). Several studies using reaction time (RT) as a perceptual latency measure found no change of RT when the test stimulus preceded the masking stimulus (Fehrer \& Raab, 1962; Fehrer \& Smith, 1962; Harrison \& Fox, 1966; Lappin \& Eriksen, 1964). Schiller and Smith (1966) found increased RT when masking and test stimulus onsets were simultaneous, and they attributed this effect to stray light. Helson and Steger (1962) did obtain increased RT when the test stimulus preceded the masking stimulus, but Lappin and Eriksen (1964) argued that the verbal "ready signal" used by Helson and Steger might have biased their results. Breitmeyer and Ganz (in press) and Weisstein, Ozog, and Szoc (1975) hypothesized that maximum reduction of test stimulus brightness occurs when the test stimulus precedes the masking stimulus because the inhibitory effects of the masking stimulus are mediated by transient neural units, whereas test stimulus brightness is mediated by sustained units. Since transient units have shorter latencies than sustained units (Breitmeyer, 1975), maximum interference with test stimulus brightness would be predicted when the test stimulus precedes the masking stimulus. Since latency would be most apt to be mediated by transient units (which respond best to moving or flickering stimuli), the effect of a masking stimulus on latency would be

This research was supported by Grant EY-00021 from the National Eye Institute, USPHS, to the first author. This paper is based on a portion of the second author's masters' thesis. expected to have a different time course than the effect of a masking stimulus on test stimulus brightness. Breitmeyer and Ganz (in press) and Weisstein (1972) both ascribe considerable theoretical importance to the finding that RT is unaffected under conditions of metacontrast.

The present experiment was conducted to study the effects of SOA on latency with the perceived-order method. Perceived-order measures have some advantage over RT, because decision-time and motor components inherent to RT are absent. Since all previous studies of latency under conditions of metacontrast used RT, the possibility remains that latency increases might have been obscured by decision time or motor component effects.

\section{METHOD}

The two subjects, J. L. and T. F., were males aged 22 and 25 years. Both had at least $20 \mathrm{~h}$ of practice prior to testing. The three-channel Maxwellian-view optical system has been described previously (Matteson, 1969). The light source was a tungsten bulb, and timing was accomplished with a digital timer. Test and comparison stimuli were 30 -min disks centered $1 \mathrm{deg} 30 \mathrm{~min}$ above and below the fixation point, respectively. The surround was $33 \mathrm{~min}$ inner diam and $1 \mathrm{deg} 30 \mathrm{~min}$ outer diam. Test and surround stimuli were presented concentrically to the right eye, and the comparison stimulus was presented to the left eye. The stimulus configuration was diagrammed in a previous paper (Flaherty \& Matteson, 1971). Test stimulus luminance was 72,000 trolands $(\mathrm{td})$ and comparison luminance was $52 \mathrm{td}$. Two surround luminances were used: 11,600 td and $104 \mathrm{td}$. Stimulus-onset asynchrony (SOA) was defined as test stimulus onset minus surround onset. For example, an SOA of +200 indicates that surround onset preceded test onset by $200 \mathrm{msec}$. Ten SOAs were used: nine values ranging from +200 to $-200 \mathrm{msec}$ and a no-surround control condition.

Points of subjective simultaneity were obtained with the perceived-order method, in which the interval between test and comparison stimuli is varied to make the occurrence of the two stimuli subjectively simultaneous (Alpern, 1954; Arden \& Weale, 1954). Two intertwined staircase series were used, and the 


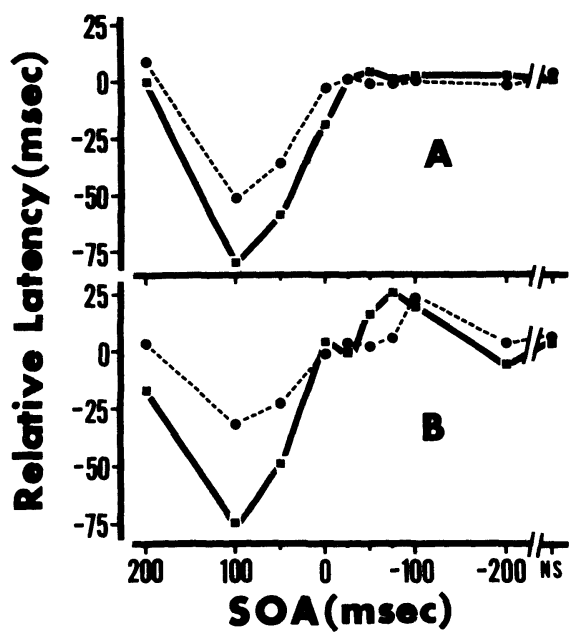

Figure 1. Mean relative latency as a function of stimulusonset asynchrony (SOA) between test and surround stimuli with a 72,000-td surround (squares, solid line) and a 104-td surround (circles, dashed line) for J. L. (A) and T. F. (B).

two series were one half step size apart. The only procedural difference from an earlier study (Matteson, 1970) was that additional trials with SOAs other than the one being measured were included. The additional trials were randomly interspersed with test trials in an attempt to force the subject to attend only to the test stimulus. Additional trials were limited to $100 \mathrm{msec}$ on either side of the SOA being measured and were multiples of $50 \mathrm{msec}$ from the SOA. For example, during determinations with an SOA of $-75 \mathrm{msec}$, the surround was also presented at asynchronies of $+25,-25,-125$, and $-175 \mathrm{msec}$. There were half as many additional trials as test trials under a given experimental condition. Subjects were dark adapted for 20 min prior to observations, and 2-min rests were given after blocks of 15 trials. Two determinations were made under each combination of experimental conditions. Determinations were made at two randomly chosen SOAs in a single session.

\section{RESULTS AND DISCUSSION}

The main effect of SOA was statistically significant for both subjects $(p<.01)$, but appreciable changes of latency occurred only when the surround preceded the test stimulus (see Figure 1). With an SOA of $+100 \mathrm{msec}$, latency was $75 \mathrm{msec}$ shorter than when no surround was presented (i.e., the comparison had to be presented $75 \mathrm{msec}$ earlier when the surround preceded the test stimulus by $100 \mathrm{msec}$.) The latency reduction at positive SOAs was greater with the high-luminance surround. The main effect of surround luminance was significant at the .01 level for both subjects. The interaction of SOA by Surround Luminance was statistically significant for T. F. $(p<.01)$, but it was not significant for J. L. $(\mathrm{p}>.05)$.

The reduction of latency when the surround preceded the test stimulus is opposite to what would be predicted from the psychological refractory period (Herman \& Kantowitz, 1970). Psychological refractory period studies involve choice RT, and increased RT obtained in these studies when another stimulus is presented prior to the test stimulus is usually explained in terms of competing response tendencies. Since the subjects did not have to choose more than one response in this experiment, an obvious explanation for shorter latencies when the surround preceded the test is that the subjects were responding to the surround rather than to the test stimulus. Previous RT studies dealt only with negative SOAs (test preceding surround).

Changes in latency at negative SOAs (test preceding surround) were negligible. J. L. showed no change of latency from -25 to $-200 \mathrm{msec}$ (Figure 1A), and these values were all very close to his latency value with no surround. With the high luminance $(11,600-$ td $)$ surround, J. L.'s latency was shorter when the surround was presented simultaneously with the test stimulus than with no surround. T. F. showed some increase of latencies at negative SOAs (Figure 1B); however, this increase was almost as large with the low luminance (104-td) surround as with the high luminance surround. With brightness-matching measures, there is no metacontrast when surround luminance is lower than test stimulus luminance (Alpern, 1953; Matteson, 1969). Thus, the small increase of latency obtained from only one subject has nothing in common with metacontrast. Perhaps it resulted from a tendency for T.F. to respond to the surround even when the test stimulus preceded the surround. Both subjects showed appreciable metacontrast with a suprathreshold brightness-matching procedure in which the luminance of the test stimulus is varied to maintain constant brightness (Flaherty \& Matteson, 1971), and these brightness measures were made over the same period of time as the latency measures reported in this paper. Flaherty and Matteson also obtained measures with a comparison stimulus adjusted to match the brightness of a constant-luminance test stimulus. These measures were highly variable and showed no evidence of metacontrast; however, the problem might well have been glare from the comparison stimulus at those SOAs where metacontrast was minimal (Growney, Weisstein, \& Cox, 1975). A low luminance comparison stimulus was used in the present experiment. Since the present study was conducted with the perceived-order method, which does not involve decision time and motor components inherent to RT, the results of the present study add generality to the conclusion that latency is unaffected under conditions of metacontrast, which is based on earlier RT studies (Fehrer \& Raab, 1962; Fehrer \& Smith, 1962; Harrison \& Fox, 1966; Lappin \& Eriksen, 1964). In terms of a recent theoretical approach to masking (Breitmeyer \& Ganz, in press; Weisstein, Ozog, \& Szoc, 1975), reduction of test stimulus brightness involves inhibition of slowresponding sustained cells by fast-responding transient cells, whereas masking of latency would involve inhibition of transient cells by transient cells. Thus, any increase of latency would be predicted to be maximal when test and masking stimuli are presented simultaneously (Schiller \& Smith, 1966). 


\section{REFERENCES}

AlPERn, M. Metacontrast. Journal of the Optical Society of America, 1953, 43, 648-657.

AlPERn, M. Relation of visual latency to intensity. American Medical Association Archives of Opthalmology, 1954, 51, 369-374.

Arden, G. B., \& Weale, R. A. Variations of the latent period of vision. Proceedings of the Royal Society (London), 1954, 142B, 258-267.

Breitmeyer, B. G. Simple reaction time as a measure of the temporal response properties of transient and sustained channels. Vision Research, 1975, 15, 1411-1412.

Brettmeyer, B., \& GANZ, L. Implications of sustained and transient channels for theories of visual pattern masking, saccadic suppression, and information processing. Psychological Review, in press.

FEHRER, E., \& RAAB, D. H. Reaction time to stimuli masked by metacontrast. Journal of Experimental Psychology, 1962, 63, 143-147.

Fehrer, E., \& SMrth, E. Effect of luminance ratio on masking. Perceptual and Motor Skills, 1962, 14, 243-253.

Flaherty, T. B., \& Matteson, H. H. Comparison of two measures of metacontrast. Journal of the Optical Society of America, 1971, 61, 828-830.

HARrison, K., \& Fox, R. Replication of reaction time to stimuli masked by metacontrast. Journal of Experimental Psychology, 1966, 71, 162-163.
Helson, H., \& Steger, J. A. On the inhibitory effects of a second stimulus following the primary stimulus to react. Journal of Experimental Psychology, 1962, 64, 201-205.

Herman, L. M., \& Kantowitz, B. H. The psychological refractory period effect: Only half of the double-stimulation story? Psychological Bulletin, 1970, 73, 74-88.

LAPPIN, J. G., \& ERIKSEN, C. W. Inhibition of simple reaction time by a second stimulus: A failure to replicate. Psychonomic Science, 1964, 1, 293-294.

MAtTESON, H. H. Effects of surround size and luminance on metacontrast. Journal of the Optical Society of America, 1969, 59, 1461-1468

Matteson, H. H. Effects of surround luminance on perceptual latency. Journal of the Optical Society of America, 1970, 60, 1125-1131.

Schiller, P. H., \& Smith, M. C. Detection in metacontrast. Journal of Experimental Psychology, 1966, 71, 32-39.

Vaughan, H. G., Costa, L. D., \& Gilden, L. The functional relation of visual evoked responses and reaction time to stimulus intensity. Vision Research, 1966, 6, 645-656.

Weisstein, N. Metacontrast. In D. Jameson \& L. Hurvich (Eds.), Handbook of sensory physiology (Vol. 7, Part 4: Visual psychophysics). Berlin: Springer-Verlag, 1972.

Weisstein, N., Ozog, G., \& Szoc, R. A comparison and elaboration of two models of metacontrast. Psychological Review, 1975, 82, 325-343.

(Received for publication February 26, 1976.) 